Guilds (Engineering) College, of which Unwin was the first professor of civil and mechanical engineering and the first dean, and to publish a biographical memoir based upon the one which was published in the Unwin Memorial issue of the Central, the journal of the City and Guilds College Old Students' Association, and so make available a record which so far has only been published for private circulation. Fuller particulars of the Committee's proposal can be obtained from the joint honorary secretaries, Messrs. G. A. Hicks and J. Severs, c/o The Institution of Civil Engineers, Great George Street, S.W.1, and contributions to the fund should be sent to the honorary treasurer, Mr. E. G. Walker, 82 Victoria Street, London, S.W.1.

\section{Communications and the Manufacturer}

THE fourth of the "Green Papers" issued by the Post Office contains a lecture by E. S. Byng to the P.O. Telephone and Telegraph Society read on January 15, 1934. He points out that the outstanding success of telephone development in the United States is attributed in some measure to the close working arrangement between the operating andmanufacturing departments of the business. In the Bell system, the various operating companies and manufacturing associations are controlled by the American Telegraph and Telephone Co. In Great Britain, the State, as owner of the whole system, does not attempt to manufacture to any appreciable extent. The production of the necessary materials and plant is rightly entrusted to industrial companies. By mutual co-operation and understanding, the Post Office and the manufacturers should be able to operate in much the same way as a single organisation. Of recent years, after work has been begun on a contract, engineers rarely ask for changes to be incorporated. Inspection in a factory may be likened to a running commentary on manufacture, as the inspection includes observing, reporting and criticising. It varies from so little as 2 per cent to 100 per cent of the total goods manufactured. Some processes call for continual vigilance, while others have mechanical safeguards against inaccurate perform. ance. The telephone dial alone consists of nearly seventy 'piece' parts each of which must be checked for accuracy of forming and its dimensions gauged between the maximum and minimum limits. In succeeding stages, the tensions of the springs are measured, the dimensions to the thousandths of an inch and the speed of operation to thousandths of a second.

\section{A New Domestic Coke}

A REPORT issued by the Department of Scientific and Industrial Research (H.M. Stationery Office, $9 d$. net) records a test by the Director of Fuel Research on a plant erected by the British Coal Distillation Co., Ltd., at Newbold, Leics., and designed to prepare a smokeless fuel from an entirely non-coking coal, high in ash. The unwashed coal is first dried and passed through a revolving inclined retort, where it is carbonised at $600^{\circ} \mathrm{C}$. by hot products of combustion of producer gas. The residue from the retort is discharged into a trough of water, and the 'clean' coke, which floats, is skimmed off the surface, while the dirt sinks and after removal is used for fuel on the plant. The resultant 'clean' coke is made with pitch into briquettes, which are stored to give a domestic fuel. The throughput of the plant as claimed-100 tons per day-was substantially confirmed, giving a fuel which was considered satisfactory for the open grate, a notable achievement for such a raw material. This is a technical test made in accordance with the normal practice of the Department, and does not purport to give an opinion about the commercial success of the process.

\section{Journal of the Royal Horticultural Society}

WIтH the publication of vol. 49, Part 3, in September 1934, the Journal of the Royal Horticultural Society became a useful and informative monthly publication instead of a quarterly or half-yearly volume. The change should be welcome to all concerned, and certainly it will enable the Society to inform members of its activities more efficiently. Lord Aberconway, president of the Society, outlined the main features of the change in the September issue. The Journal has maintained a high standard. of learning, science and practice for nearly fifty years, and has grown from a tiny circulation to a very large one. The new arrangement is designed "to add rather than to replace. ... Records will be more up-to-date; news can be given while it is still fresh; information of coming events can be made available; notes of more immediate interest can be introduced; the most recent information as to the Society's activities at Wisley can be included". The "Book of Arrangements" will no longer be issued, but the information will be included in the January and February numbers of the Journal. The parts which have appeared since the change was effected show that the standard is even higher, if that is possible, than of old, whilst the total volume of subject-matter seems to have increased.

\section{National Research Council, Canada}

ThE seventeenth annual report, for 1933-34, of the National Research Council of Canada, in addition to reviewing the researches on analysis and testing conducted in the National Research Laboratories, gives a summary of the activities of associate committees and of assisted researches in university and other laboratories and under scholarships. A financial statement is included, together with particulars of the personnel of the varjous research, advisory and special committees. Among the researches completed in the National Research Laboratories during the year may be mentioned investigations on the suitability of Canadian clays for oil-refining, the bonding of rubber to metal, the chemical investigation of Canadian weeds poisonous to livestock, the suitability of Canadian wools for the manufacture of cloth, the causes of premature seeding in turnips, the stability of aircraft floats and the correction of instability in aircraft used for photographic survey work. Researches conducted under associate committees have dealt with methods for combating losses due to 